IBT Journal of Business Studies

Volume 15(1), 2019, 33-45

\title{
Factors Influencing Career Choices
}

\author{
Nimra Sharif ${ }^{1^{*}}$ \\ Nawaz Ahmad ${ }^{2}$ \\ SamiUllah Sarwar ${ }^{3}$
}

\begin{abstract}
Almost every individual is to face the challenge of the occupational choice problem at one or another time. However, students are particularly to encounter such problem while the selection of study programmes. It is widely believed, particularly by students, that selection of study programmes is the major factor, which leads the students to struggle for their desired future career. This study attempted to explore the roles of mothers, fathers, tutors, future income, future status, and societal difference by labelling all of such factors as "Influencers" on the career choice of young students. From this perspective, cross-sectional data based on primary data collection was gathered from different university students based in Karachi via a developed questionnaire and through nonprobabilistic convenience sampling. The gathered data was, subsequently, analyzed through one sample t-test and one way repeated Measure ANOVA by employing SPSS statistical package. The result of the study highlighted the relative importance of various career choice influences\& that averages of variables of influence are statistically different $F(4.215,699.727)=27.405, p<0.05$. These results could be used to make the student opt the right career path and excel in the desired domain.
\end{abstract}

Keywords: Career Influences, university students, cross-sectional data.

1- PhD Scholars at IoBM, Karachi, email:nimra615@live.co.uk

2- Assistant Professor at IoBM, Karachi,email:nawazahmad_pk@hotmail.com

3-PhD Scholars at IoBM, Karachi, email: learnedsami@gmail.com 


\section{INTRODUCTION}

Selection of thedesired career can be stated as the top most priority of every individual in the world. Nevertheless, students at college level seem more worried about their future career. From this perspective, Nyamwange (2016) points out that every individual is to face the challenge of theoccupational choice problem at one or another time. However, students are particularly to encounter such problem while the selection of study programmes. It is widely believed, particularly by students, that the selection of study programmes is the major factor, which leads the studentsto struggle for their desired future career (Theresa, 2015). It would not be wrong to state that selection of study programmes is based on the selection of future career. Therefore, the wrong selection of study programmes leads the students towards anundesired future career.

Nyamwange (2016) argues that selection of the desiredcareer is a difficult and not a straightforward undertaking, as it requires specialization at aworkplace, which means individuals must have specializededucational background prior to embarking on the practical life. On the other hand, individuals must be good decision makers prior to the selection of educational background. According to Korkmaz (2015), various factors such asextrinsic and intrinsic (or both combined) have asignificant influenceon the career choices of individuals. From this perspective, the intrinsic factors are based on the interests, personality, self-concept, cultural identity, and attitudes of individuals. In contrast, the extrinsic factors are based onsocial contacts, availability of respective resources including information and finances, role models, globalization, level of educational accomplishment, ethnic background, and so on. Nevertheless, one of the most significant issues is the decision making, particularly when it comes to taking admission for a specific study programme. Like other countries, choosing theright future career has become an important factor for young students in Pakistan as well.Students in Pakistan are expected to consider certain factorswhile choosing their future career as well as college majors.Nevertheless, a wide range of factors influencesthe decision of students regarding the selection of college majors or future career. Some of the factors include parents and parenting styles (Sarwar, 2016), religious figures, coaches, or any role models in the life of students. Despite a large number of research studies exploring the factors influencing the decision of students regarding their future career, it is a big issue for most of the students to understand such factors. This study attempts to explore the roles of mothers, fathers, tutors, future income, future status, and societal difference by labelling as "Influencers" on the career choice of young students.From this perspective, it attempts to answer the following question:

What are the roles of influencers in choosing afuture careerby students in Pakistan?

With this research Question different research hypotheses for this study are as Follows:

$\mathrm{H} 1$ :variable of the mother has no significant impact on the career choices of students.

$\mathrm{H} 2$ : variable of the father has no significant impact on the career choices of the students.

$\mathrm{H} 3$ : variable of tutor has no significant impact on the career choices of the students.

H4variable of future income has no significant impact on the career choices of the student.

H5: variable of societal difference has no significant impact on the career choices of the students.

H6: variable of future status has no significant impact on the career choices of the students.

H7: different variable does not differ in their level of influence on the career choicesof the students. 


\section{LITERATURE REVIEW}

\section{Mother Influence on Young Students' Career Choice}

Rani (2014) conducts astudy to explore the impact of parenting style on the career choice of students and found that parents play a key role in the career development of students. While determining the influence of parents on the decision of African American students, Hairston (2000) found, "In early adulthood, many African American children, particularly African American females are influenced by the aspirations of their mothers"(p. 7). Hairston (2000) further explains that mothers are cited as influential figures, particularly because they provide their children with support, whicheases the apprehensions of students about career choice. Considering this factor, Hairston (2000) believes a strong influence of mothers on the career choice of students. Working on a study, O'brien, Friedman, Tipton, and Linn (2000)investigate the career aspiration and career self-efficacyof young women in the light of separation from and attachment to parents. The findings of the study revealed, "Attachment to mother had a significant direct effect on career self-efficacy, and career self-efficacy again influenced career aspiration" (p. 309).

\section{Father Influence on Young Students' Career Choice}

According to Allen and Daly (2007), spending the time with children for the sake of taking their care provides the fathers with opportunities to show their affection towards their children. It always assists them to nurture their children. Exploring a range of factors that may influence choosing acareerby the management students in India, Agarwala (2008) found, "Skills, competencies, and abilities were the most important factor and father was the most significant individual influencing the career choice of Indian management students" (p. 362). While determining the influence of certain factors including gender, age, location, paternal and maternal occupation as well as their education levelson the career preferences of students in Malaysia, Huern, Khairuddin, Ismail, and De (2015) found that not only the fathersbut also occupations also play a significant role in thepreference of career path of children.

\section{Tutor Influence on Young Students' Career Choice}

Conducting astudy on South African students regarding their career choice, Shumba and Naong (2012) found that teachers were the most significant factors influencing the aspirations and career choice of students. Citing Barnett (2007), Shumba and Naong (2012) also figured out that as parents, teachers are also viewed as crucial playersfor the career path, which young students are eventually to pursue in their future lives. In the same way, Faitar and Faitar (2013) attempting to understand the guidance of teachers and the extent it helps the students choose science-oriented careers found that "an early attention to students' skills and aptitudes, especially when dealing with minority and/ or underprivileged ones, is critical in encouraging them to follow future STEM careers" (p. 10). Investigating the factors influencing the career selection of student, Ahmed, Sharif, and Ahmad (2017) explored the need of counselling sessions and similar other interventions for students that can build their interest in the available options and theright choice of career.

\section{Future Income}

According to Edwards and Quinter (2011), most of the students give priority to the career their 
IBT Journal of Business Studies Volume 15(1), 2019

parents prefer, other follow that their educational backgrounds have opened for them, some choose to follow their passion without considering the outcome, and some give preference to the career that can bring high income in their future. Conducting astudy to identify the major factors inducing the Pakistani graduatesfor their career choice, Abbasi,and Sarwat (2014) explored that salary structured was among one of the significant factors that influence the career choice of graduate students in Pakistan. According to the results of the study conducted by Wilson and Donnelly (2011), "The most important factor for students that entered industry or have an interest in the private sector was salary, followed by lifestyle" (p. 5).

\section{Future Status}

According to Bhattacharya (2013), thecareerof an individual can be stated traditionally as a course of thesuccessive situation, which makes up the work life of that individual. In the modern and fastchangingworld, students are more intended to seek their career that ultimately leads them towards good status in their society.

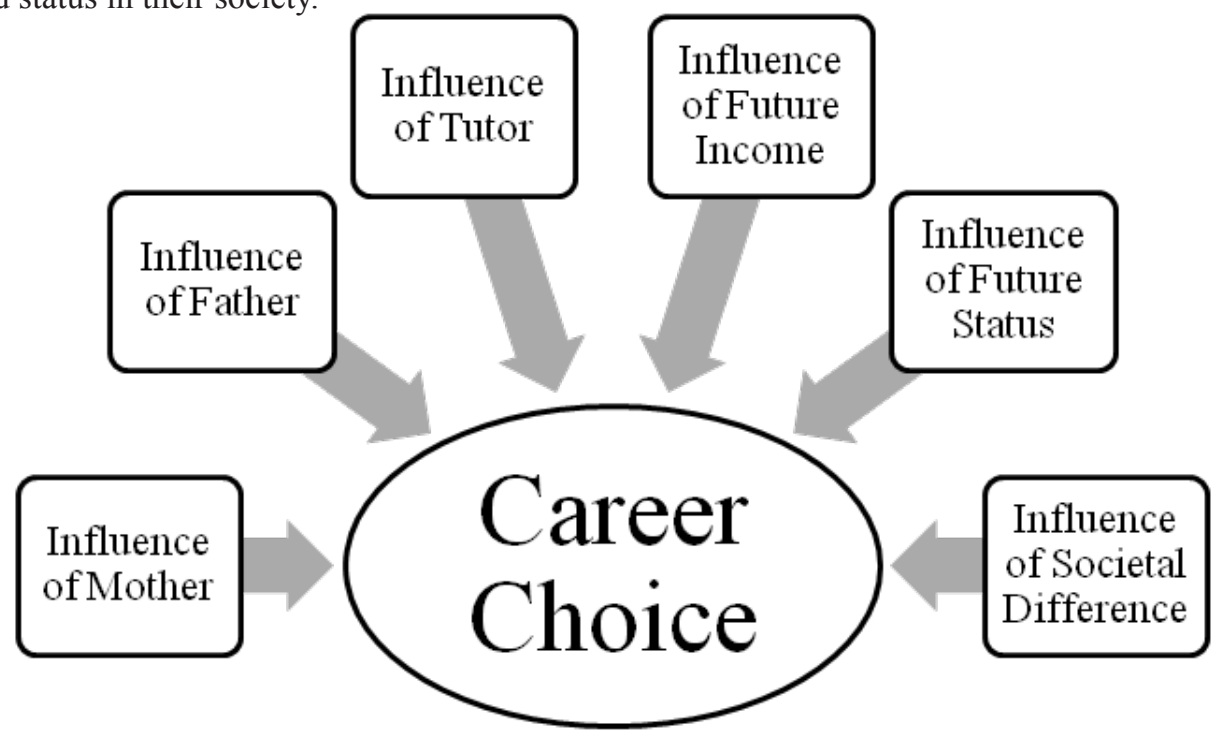

Figure 1: Framework

\section{METHODOLOGY}

\section{Data:}

The cross-sectionaldata collected for this comparative study is primary in nature. The respondent has given direct responses toparticular Questions asked fromthem. They rated each Question based on their Agreement level on it.

\section{Variables of the research:}

The variables of this research are termed career influences. The career influences are factors 
that could be a part of an individual's career decision-making processes or that could direct an individual's career decision. Six career influences, which are mother, father, tutor, future status, future income and making difference in society, are taken on ascale to highlight their effect on career choice decision.

\section{Sample \& Target Population:}

The Research participants consisted of different university students of Karachi. The participants are selected disregard to their discipline they are enrolled in, or their Age. The findings of the research could be generalized to an average student studying at the University of Karachi highlighting their career decision-influencing factors.

\section{Research instrument:}

The adopted research instrument, used for this research gained its roots from the Questionnaire developed by Daire, LaMothe \& Fuller (2007). The Questionnaire was termed as CIIQ (Career Involvement \& Influence Questionnaire). This Questionnaire originally consisted of two sectionsone for pure Quantitative data and one section for Qualitative assessment of responses. We have taken the Quantitative section of CIIQ for our Analysis. It will assess the different influences on the career choices of a student. The close-ended Questions wouldevaluate the potential influence enforced by these factors on career choices with a 1-5Likert scale.

\section{Sample Size \& Sampling Techniques:}

Participant's selection for the sample is based on non- probabilistic, convenience sampling technique. In the beginning, 180 sample size was selected for applying repeated Measure ANOVA with $80 \%$ of statistical power but due to a number of incomplete Questionnaires only 167 Questionnaire Qualified to be part of the study and contributing towards its analysis.

\section{Statistical Technique:}

For the current study,one sample t-testand a one way repeated Measure ANOVA research technique is applied. Since the same participant rated on different career influences and a comparison is done by the means of these career influences. The Analysis would be based on factors should be answered by the same cases (e.g. participant) in order to apply this technique since it is considered as an extension of thematched paired test.

\section{RESULTS AND FINDINGS}

The results of the study can be highlighted with the help of tables and interpretations given below.

\section{Descriptive Analysis:}

a) The demographic profile of Respondents: 
Table 1: Demographic

\begin{tabular}{|l|l|l|}
\hline AGE & Frequency & Percent \\
\hline under 18 & 20 & 12.0 \\
\hline $18-24$ & 119 & 71.3 \\
\hline $25-35$ & 28 & 16.8 \\
\hline EDUCATION & Frequency & Percent \\
\hline intermediate & 28 & 16.8 \\
\hline undergraduate & 102 & 61.1 \\
\hline graduate & 37 & 22.2 \\
\hline GENDER & Frequency & Percent \\
\hline female & 70 & 41.9 \\
\hline male & 97 & 58.1 \\
\hline Total & 167 & 100.0 \\
\hline
\end{tabular}

Majority of our respondents $71 \%$ belong to the age bracket of $18-24$ since it's an average age for individuals studying in any university. 12 and $16.8 \%$ of the respondents belong to other age brackets. $61 \%$ of them are undergraduatestudents whereas, 16.8 and $22.2 \%$ are intermediate and graduates. out of 167, 70 are females and 97 are males.

b) Factors influencing Career Choices:

Table 2: Within-Subjects Factors

\begin{tabular}{|l|l|}
\hline Measure: & MEASURE \\
\hline Influencing_Factors & Career choice influences \\
\hline 1 & Mother \\
\hline 2 & Father \\
\hline 3 & Tutor \\
\hline 4 & Future Income \\
\hline 5 & Future status \\
\hline 6 & Societal Difference \\
\hline
\end{tabular}

Table two highlights the different career choice influences considered for the study. One sample t-test and one way repeated Measure ANOVA are applied to these six influences, rated by an individual as affecting its career decision-making process. 


\section{c) Examination Of Means\& Standard Deviations:}

Table 3: Descriptive Statistics

\begin{tabular}{|l|l|l|l|}
\hline & Mean & Std. Deviation & $\mathrm{N}$ \\
\hline Mother & 2.9760 & 1.42673 & 167 \\
\hline Father & 3.6347 & 1.38564 & 167 \\
\hline Tutor & 2.9760 & 1.31695 & 167 \\
\hline Future Income & 3.8922 & 1.10328 & 167 \\
\hline Future Status & 4.1018 & .97952 & 167 \\
\hline Societal Difference & 3.6407 & 1.14714 & 167 \\
\hline
\end{tabular}

Since the career choices influences were rated on 5 pointsLikert scale from highest to lowest, it could be observed future status $(4.1018+.97952)$, Future Income $(3.8922+1.10328)$, the societal difference $(3.6407+1.14714)$ and father influence $(3.6347+1.38564)$ has recordedmore than average responses. Furthermore, mother $(2.9760+1.42673)$ and tutors $(2.9760+1.31695)$ influences are more or less same and closer to average response.

\section{Graphical Analysis:}

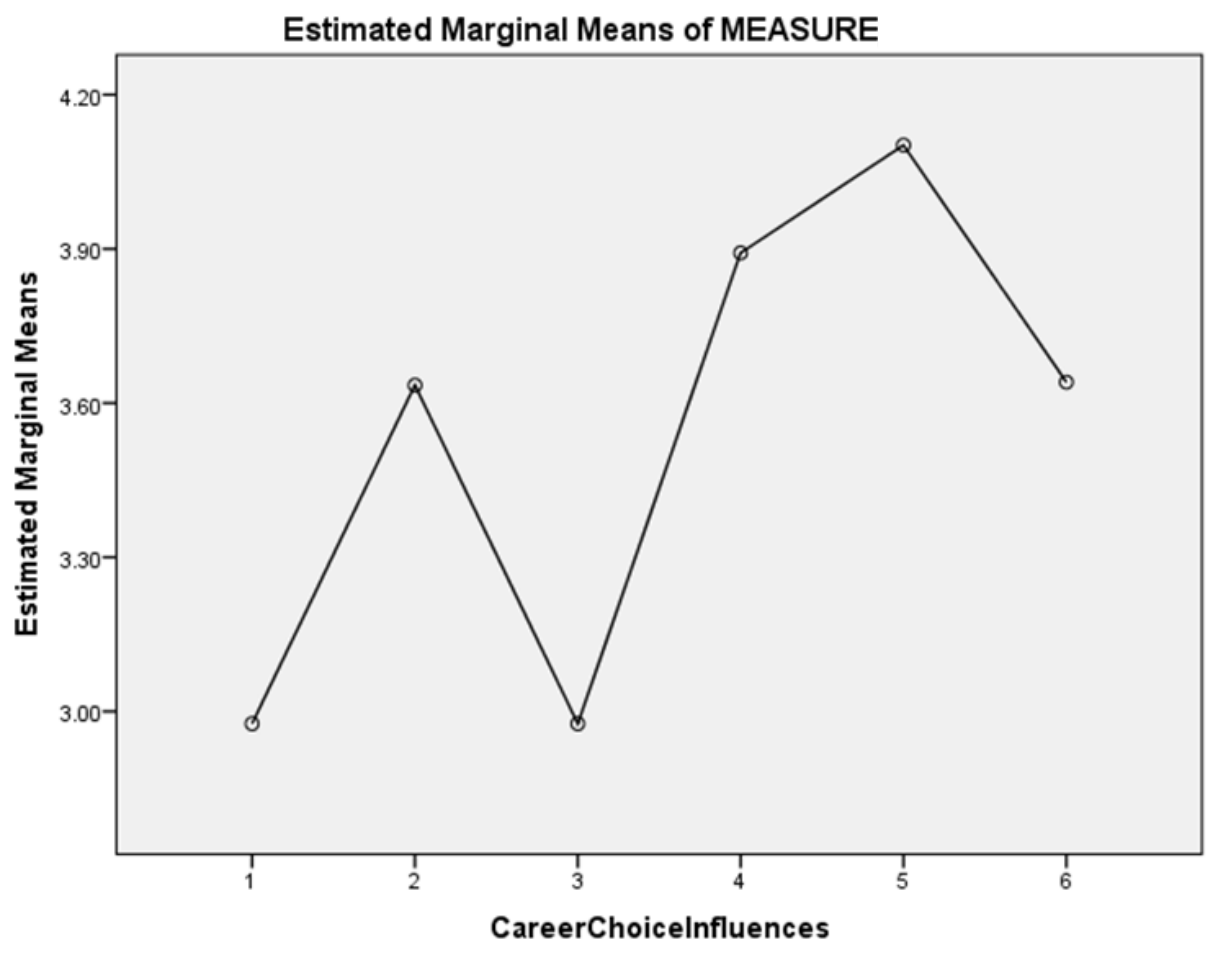




\section{Figure 2:}

The graphical Analysis also highlights that the major influencer, having peaked in the graph,inthe career decision making of an individual is factor 5, which is future status. Whereas, mother and tutor as factor 1 and 3 respectively, lacking their influence in the career choice, are highlighted as a lowest mean point in the graph.

\section{Inferential Analysis:}

The individual variable significanceis tested via one sample t-test while taking 3 as the test value. Whereas, the mean comparison is conducted by repeated Measure Anova.

\section{a) individual Variable Significance:}

Table 4: One-Sample Test

\begin{tabular}{|l|l|l|l|l|l|l|}
\hline & & & \multicolumn{3}{|c|}{ Test Value 3} & \\
\hline & $\mathrm{t}$ & $\mathrm{df}$ & $\begin{array}{l}\text { Sig. } \\
(2 \text {-tailed })\end{array}$ & $\begin{array}{l}\text { Mean } \\
\text { Difference }\end{array}$ & $\begin{array}{l}\text { 95\% Confidence Interval of } \\
\text { the Difference }\end{array}$ \\
\hline & & & & & Lower & Upper \\
\hline Mother & -.217 & 166 & .829 & -.02395 & -.2419 & .1940 \\
\hline father & 5.920 & 166 & .000 & .63473 & .4230 & .8464 \\
\hline tutor & -.235 & 166 & .814 & -.02395 & -.2252 & .1773 \\
\hline $\begin{array}{l}\text { Future } \\
\text { Income }\end{array}$ & 10.451 & 166 & .000 & .89222 & .7237 & 1.0608 \\
\hline Future Status & 14.536 & 166 & .000 & 1.10180 & .9521 & 1.2514 \\
\hline $\begin{array}{l}\text { Difference in } \\
\text { Society }\end{array}$ & 7.218 & 166 & .000 & .64072 & .4655 & .8160 \\
\hline
\end{tabular}

It can be well observed from the above table that the variable of mothert $(166)=-.217, p=.829$ and tutor $\mathrm{t}(166)=-.235, \mathrm{p}=.814$ arelacking their statistical significance. Furthermore, the variables of father $\mathrm{t}(166)=-5.920, \mathrm{p}=.000$, Future Income $\mathrm{t}(166)=10.451, \mathrm{p}=.000$, Future Status $1 \mathrm{t}(166)$ $=14.536, p=.000$ and societal Difference $\mathrm{t}(166)=-7.218, \mathrm{p}=.000$ are significant in influencing students career choice. Hence, from one sample t-test,we could reject $\mathrm{H} 1, \mathrm{H} 3$ and retain $\mathrm{H} 2, \mathrm{H} 4$, H5, and H6. 


\section{b) Application of Repeated Measure ANOVA:}

\section{i. Testing of sphericity:}

Table 5: Mauchly's Test of Sphericity

\begin{tabular}{|l|l|l|l|l|l|l|l|}
\hline \multicolumn{9}{|c|}{ Measure: MEASURE_1 } \\
\hline $\begin{array}{l}\text { Within- } \\
\text { Subjects Effect }\end{array}$ & Mauchly's W & $\begin{array}{l}\text { Approx. Chi- } \\
\text { Square }\end{array}$ & df & Sig. & Epsilon & & \\
\hline & & & & & $\begin{array}{l}\text { Greenhouse- } \\
\text { Geisser } \\
\text { Feldt }\end{array}$ & $\begin{array}{l}\text { Huynh- } \\
\text { bound }\end{array}$ \\
\hline $\begin{array}{l}\text { Influencing- } \\
\text { Factors }\end{array}$ & .450 & 131.124 & 14 & .000 & .820 & .843 & .200 \\
\hline
\end{tabular}

The null hypothesis for atest of Sphericity by Mauchly's state that within-subject differences equal variance is supposed. Since $\mathrm{P}=000$ null rejected so the Assumption is violated chi squared=.131.124.

\section{ii. Testing for Repeated Measure ANOVA Null Hypothesis:}

Violation of Sphericity assumption \& epsilon value greater than 0.75 opens the door for HuynhFeldt correction (Maxwell \& Delaney, 2004).

Table 6: Tests of Within-Subjects Effects

\begin{tabular}{|c|c|c|c|c|c|c|c|}
\hline \multicolumn{8}{|c|}{ Measure: MEASURE_1 } \\
\hline Source & $\begin{array}{l}\text { Type III Sum of } \\
\text { Squares }\end{array}$ & Df & $\begin{array}{l}\text { Mean } \\
\text { Square }\end{array}$ & $\mathrm{F}$ & Sig. & $\begin{array}{l}\text { Partial } \\
\text { Eta } \\
\text { Squared }\end{array}$ & \\
\hline \multirow{4}{*}{$\begin{array}{l}\text { Influencing } \\
\text { Factors }\end{array}$} & Sphericity Assumed & 182.834 & 5 & 36.567 & 27.405 & .000 & .142 \\
\hline & Greenhouse-Geisser & 182.834 & 4.099 & 44.610 & 27.405 & .000 & .142 \\
\hline & Huynh-Feldt & 182.834 & 4.215 & 43.375 & 27.405 & .000 & .142 \\
\hline & Lower-bound & 182.834 & 1.000 & 182.834 & 27.405 & .000 & .142 \\
\hline \multirow{4}{*}{$\begin{array}{l}\text { Error } \\
\text { (Influencing } \\
\text { Factors) }\end{array}$} & Sphericity Assumed & 1107.499 & 830 & 1.334 & & & \\
\hline & Greenhouse-Geisser & 1107.499 & 680.353 & 1.628 & & & \\
\hline & Huynh-Feldt & 1107.499 & 699.727 & 1.583 & & & \\
\hline & Lower-bound & 1107.499 & 166.000 & 6.672 & & & \\
\hline
\end{tabular}

Using Huynh-Feldt statistics since the Epsilonvalue is greater than 0.75. The Huynh-Feldt rows of the table will notify that means of the criterion variable are statistically meaningfully different 
IBT Journal of Business Studies Volume 15(1), 2019

for the changing influencesof the within-subjects factor (i.e., whether averages of influences are statistically different between mother, father, future income, tutor, making difference in society \& Future Status ). Since the sig value $=.000$ so there exist a difference. Averages of variables of influence are statistically different $F(4.215,699.727)=27.405$, $\mathrm{p}<0.05$ so Null hypothesis is Rejected.

\section{iii. Effect size :}

The effect size for highlighting variability within-subject factor is given by partial Eta Squared.

Table 7: Tests of Within-Subjects Effects

\begin{tabular}{|l|l|l|l|l|l|l|l|}
\hline \multicolumn{9}{|c|}{ Measure: MEASURE_1 } \\
\hline Source & $\begin{array}{l}\text { Type III Sum of } \\
\text { Squares }\end{array}$ & df & $\begin{array}{l}\text { Mean } \\
\text { Square }\end{array}$ & F & Sig. & $\begin{array}{l}\text { Partial } \\
\text { Eta } \\
\text { Squared }\end{array}$ & \\
\hline $\begin{array}{l}\text { Influencing } \\
\text { Factors }\end{array}$ & Sphericity Assumed & 182.834 & 5 & 36.567 & 27.405 & .000 & .142 \\
\hline & Greenhouse-Geisser & 182.834 & 4.099 & 44.610 & 27.405 & .000 & .142 \\
\hline & Huynh-Feldt & 182.834 & 4.215 & 43.375 & 27.405 & .000 & .142 \\
\hline $\begin{array}{l}\text { Error } \\
\text { Influencing }\end{array}$ & Lower-bound & 182.834 & 1.000 & 182.834 & 27.405 & .000 & .142 \\
\hline & Sphericity Assumed & 1107.499 & 830 & 1.334 & & & \\
\hline & Greenhouse-Geisser & 1107.499 & 680.353 & 1.628 & & & \\
\hline & Huynh-Feldt & 1107.499 & 699.727 & 1.583 & & & \\
\hline & Lower-bound & 1107.499 & 166.000 & 6.672 & & & \\
\hline
\end{tabular}

While spotting epsilon value of .843 for Huynh-Feldt test, it could be concluded that there exists a Statistically significant difference in at least one pair of above factors, influencing career choice of student $\mathrm{F}(4.215,699.727)=27.405, \mathrm{p}<0.05$, partial $\eta 2=.142$.

\section{iv. Post Hoc Test for Multiple Group Comparison:}


Table 8: Pairwise Comparisons

Pairuvise Comparisons

Measure: MEASURE 1

\begin{tabular}{|c|c|c|c|c|c|c|}
\hline \multirow[t]{2}{*}{ (I) CareerChoiceInfluences } & \multirow[t]{2}{*}{ (J) CareerChoiceInfluences } & \multirow{2}{*}{$\begin{array}{c}\text { Mean } \\
\text { Difference } \\
\text { (I-J) } \\
\end{array}$} & \multirow[t]{2}{*}{$\begin{array}{l}\text { Std. } \\
\text { Error }\end{array}$} & \multirow[t]{2}{*}{$\mathrm{Sig}_{\mathrm{b}}^{\mathrm{b}}$} & \multicolumn{2}{|c|}{$\begin{array}{l}\text { 95\% Confidence Interval for } \\
\text { Differenceb }\end{array}$} \\
\hline & & & & & Lower Bound & Upper Bound \\
\hline \multirow{5}{*}{ Mother } & Father & $-.659^{*}$ & .152 & .000 & -1.112 & -.205 \\
\hline & Tutor & .000 & .143 & 1.000 & -.426 & .426 \\
\hline & Future income & $-.916^{*}$ & .133 & .000 & -1.312 & -.520 \\
\hline & Future status & $-1.126^{*}$ & .126 & .000 & -1.501 & -.750 \\
\hline & Societal Difference & $-.665^{\circ}$ & .121 & .000 & -1.026 & -.304 \\
\hline \multirow{5}{*}{ Father } & Mother & $.659^{*}$ & .152 & .000 & .205 & 1.112 \\
\hline & tutor & $.659^{*}$ & .143 & .000 & .232 & 1.086 \\
\hline & Future income & -.257 & .116 & .407 & -.602 & .087 \\
\hline & Future status & $-.467^{*}$ & .120 & .002 & -.826 & -.109 \\
\hline & Societal Difference & -.006 & .129 & 1.000 & -.389 & .377 \\
\hline \multirow{5}{*}{ Tutor } & Mother & .000 & .143 & 1.000 & -.426 & .426 \\
\hline & Father & $-.659^{*}$ & .143 & .000 & -1.086 & -.232 \\
\hline & Future income & $-.916^{\circ}$ & .140 & .000 & -1.333 & -.499 \\
\hline & Future Status & $-1.126^{\circ}$ & .131 & .000 & -1.515 & -.737 \\
\hline & Societal Difference & $-.665^{\circ}$ & .140 & .000 & -1.081 & -.249 \\
\hline \multirow{5}{*}{ Future Income } & Mother & $.916^{\circ}$ & .133 & .000 & .520 & 1.312 \\
\hline & Father & .257 & .116 & .407 & -.087 & .602 \\
\hline & Tutor & $.916^{\circ}$ & .140 & .000 & .499 & 1.333 \\
\hline & Future Status & $-.210^{*}$ & .068 & .035 & -.412 & -.007 \\
\hline & Societal Difference & .251 & .106 & .282 & -.064 & .567 \\
\hline \multirow{5}{*}{ Future Status } & Mother & $1.126^{\circ}$ & .126 & .000 & .750 & 1.501 \\
\hline & Father & $.467^{\circ}$ & .120 & .002 & .109 & .826 \\
\hline & Tutor & $1.126^{\circ}$ & .131 & .000 & .737 & 1.515 \\
\hline & Future Income & $.210^{*}$ & .068 & .035 & .007 & .412 \\
\hline & Societal Difference & $.461^{\circ}$ & .104 & .000 & .150 & .772 \\
\hline \multirow{5}{*}{ Societal Difference } & Mother & $.665^{\circ}$ & .121 & .000 & .304 & 1.026 \\
\hline & Father & .006 & .129 & 1.000 & -.377 & .389 \\
\hline & Tutor & $.665^{\circ}$ & .140 & .000 & .249 & 1.081 \\
\hline & Future Income & -.251 & .106 & .282 & -.567 & .064 \\
\hline & Future Status & $-.461^{*}$ & .104 & .000 & -.772 & -.150 \\
\hline
\end{tabular}

Based on estimated marginal means

*. The mean difference is significant at the .05 level.

b. Adjustment for multiple comparisons: Bonferroni.

The post hoc test clarifies the statistical difference between the means of various groups. it could be well observed that future status with highest influencing power $(4.1018+.97952)$, statistically differs from all another group of influencers $(\mathrm{p}<0.05)$. The mother $(2.9760+1.42673)$ and tutors 
IBT Journal of Business Studies Volume 15(1), 2019

$(2.9760+1.31695)$ are having same influencing power since their mean difference $=.000$ and $\mathrm{P}>0.05$

\section{DISCUSSION}

The results of our study are in favour of the fact that the father plays an important role in the development of or influencing decision-related to their child's career within eastern society (Agarwala, 2008). The career for which the student found that their future income would be high is also mostly opted by an individual. They would refrain from the career path that would end up in an average monthly income( Abbasi and Sarwat, 2014). While considering influences one of the career choice influences that remain on the top list almost majority of the students is their future status. The would love to opt for the career that could give them a boost in the society, having to afford them a lavish lifestyle. Not only our study but a number of previous studies gave the same findings (Bhattacharya, 2013).

\section{CONCLUSION}

Student's plays there career decision on a variety of factors. This study provides a comparative analysis of various factors that shape an individual's career decision. This study will highlights that for a career decision taken by an individual there exist a number of influences. Among these influences, the most powerful ones are theinfluence of earning a reputable social status, income, making difference in society and fathers pressure to take a move in a particular direction. These all influences are not mere influences they shape the future of the society since career choice decision even of a single individual is very important for a society.

\section{REFERENCES}

Abbasi, M. N., \& Sarwat, N. (2014). Factors Inducing Career Choice: Comparative Study of Five Leading Professions in Pakistan. Pakistan Journal of Commerce \& Social Sciences, 8(3).

Ahmed, K. A., Sharif, N., \& Ahmad, N. (2017). Factors Influencing Students' Career Choices: Empirical Evidence from Business Students. Journal of Southeast Asian Research. IBIMA Publishing.

Allen, S. M., \& Daly, K. J. (2007). The effects of father involvement: An updated research summary of the evidence. Centre for Families, Work \& Well-Being, University of Guelph.

Agarwala, T. (2008). Factors influencing career choice of management students in India. Career Development International, 13(4), 362-376.

Barnett, R. C. (2007). Understanding the role of pervasive negative gender stereotypes: What can be done?. Heidelberg, Germany: Brandeis University

Bhattacharya, S. (2013). A Study On Parental And Social Influence On Career Choice As Engineer (No. 2013-6-3).

Daire, A., LaMothe, S., \& Fuller, D. (2007). Differences between black/African American and white college students regarding influences on high school completion, college attendance, and career choice. The Career Development Quarterly, 55, 275-279.

Edwards, K., \& Quinter, M. (2011). Factors influencing students career choices among secondary school students in Kisumu municipality, Kenya. Journal of Emerging Trends in Educational Research and Policy Studies, 2(2), 81-87.

Faitar, G., \& Faitar, S. (2013). Teachers' influence on students' science career choices. American International Journal of Social Science, 2(5), 10-16.

Huern, S. Y., Khairuddin, K. A., Ismail, A., \& De, S. (2015). Career Preference amongst Year 10

Page $\mid 44$ 
Students in Malaysia: A Pilot Study. British Journal of Education, Society and Behavioural Science, 6(2), 87-94.

Korkmaz, H. (2015). Factors Influencing Students' Career Chooses in Science and Technology: Implications for High School Science Curricula. Procedia-Social and Behavioral Sciences, 197, 966-972.

Rani, B. S. (2014). Impact of parenting styles on the career choices of adolescents. Journal of Education and Social Policy, 1(1), 19-22.

Hairston, J. E. (2000). How parents influence African American students' decisions to prepare for vocational teaching careers. Journal of career and technical education, 16(2).

Nyamwange, J. (2016). Influence of Student's Interest in Career Choice among First Year University Students in Public and Private Universities in Kisii County, Kenya. Journal of Education and Practice, 7(4), 96-102.

O’brien, K. M., Friedman, S. M., Tipton, L. C., \& Linn, S. G. (2000). Attachment, separation, and women's vocational development: A longitudinal analysis. Journal of Counseling Psychology, 47(3), 301.

Sarwar, S. (2016). Influence of Parenting Style on Children's Behaviour. Journal of Education and Educational Development, 3(2), 222-249.

Theresa, L. D. (2015). Factors That Inform Students' Choice of Study and Career. Journal of Education and Practice, 6(27), 43-49.

Shumba, A., \& Naong, M. (2012). Factors influencing students' career choice and aspirations in South Africa. J Soc Sci, 33(2), 169-178.

Wilson, D., \& Donnelly, A. (2011). Assessing the Factors that Influence the Career Choices of Minority PhD Graduates in SEM Fields. Women in Engineering ProActive Network. 